\title{
PALAVRAS DO DIRETOR *
}

Senhores Professores.

Senhoras.

Senhores.

Alunos desta Faculdade de Direito.

Quiz o destino que eu viesse a ocupar o cargo de Diretor da legendária e tradicional Faculdade de Direito da Universidade Federal do Paraná, no momento eufemisticamente denominada de Setor de Ciências Jurídicas, a fim de consolidar a sua restauração jurídica. Comecei a cumprir a tarefa, pois, ao ser obrigado a tomar posse via de liminar em ação de segurança, defendi o princípio da livre e autônoma administração desta Escola, tradição conquistada a que não tenho o direito de renúncia. A negativa da posse, sob o falso pretexto da inexistência do cargo, buscou ferir um direito que não é meu - o da autonomia administrativa da Faculdade de Direito no aspecto da livre escolha dos seus dirigentes - e que, por isso mesmo, é por mim, ainda que me fosse mais cômodo, irrenunciável.

Sei que a tarefa será árdua, mas para isso creio contar com os meus pares do corpo docente, a quem aprendi a respeitar pelos concursos públicos e pela produção científica, pela dedicação monástica e desinteressada da imediata contraprestação, porque compensado pela multiplicação do saber jurídico. A mística do concurso público sério e rigoroso para os cargos docentes, este o esteio da legitimidade do professor de Direito. Espero contar com o corpo discente, que deve saber das suas responsabilidades por ocupar vagas em uma escola pública, sustentada pelo esforço dos muitos que não podem frequientá-la, mesmo que seja por seus descendentes.

Para mim a Faculdade é uma relação em que os polos estão ocupados pelos corpos docente e discente, numa interação completa e dependencial, em que a finalidade, o escopo, a meta maior é o ensino, o ensino sério, o ensino sacrificado, o ensino total do Direito. Na minha

\footnotetext{
* Prof. Luiz Alberto Machado

Discursa de Aceitação, proferido em novembro de 1984.
} 
visão a Faculdade de Direito é uma proposta política permanente. É um cadinho em que se misturam todas as matérias sociais. É o laboratório experimental dos novos pactos de poder. POULANTZAS, abominando o estado absenteista, o estado do "laissez-faire", e o estado intervencionista, o estado totalitário, o grande burocrata, sempre presente, afirmou que o estado moderno é uma relação entre as facções, minoritárias e majoritárias, no poder e fora dele. Nesta própria Casa o ilustre Professor MIGUEL SEABRA FAGUNDES disse que as leis são necessárias às minorias: à maioria, basta ser a maioria. Permito-me interpretar essas posições no sentido de que o Estado moderno, o Estado de Direito democrático moderno traduz um pacto de poder em contínua mutação, em permanente evolução. E é nesse debate de idéias, amplo e apaixonado mas sincero e leal - e sobretudo educado - , na integração $e$ na interação dos professores e dos alunos, que desejo ver surgir propostas políticas para uma sociedade moderna, mais justa, mais estável, inimiga do maniqueismo estreito e adepta de um espectro abrangente de participação democrática. EDMUND BURKE, político inglês do século XVIII, disse:

"A verdade pode apenas ser enunciada por tentativas, através de convenções, e confirmada, de um modo imperfeito, pela experiência; a verdade nunca será estabelecida a partir da sua auto-evidência, nunca é fixa e imutável'".

(KARL DEUTSCH, Política e Governo, Ed. Universidade de Brasília, p. 125)

A verdade não provém da revelação, como quiz ROUSSEAU, permitindo a ROBESPIERRE o fundamento para o seu pretenso "despotismo esclarecido", que conduziu à guilhotina a cabeça dos não iluminados. A verdade é uma busca constante, séria, apaixonada e apaixonante, que, por isso mesmo, não pode permitir a ação que KARL DEUTSCH chamou de "política de barganha", imobilista pelos compromissos conflitantes, sempre resultando em uma atuação emergencial.

Por isso não acredito nas pessoas de um livro só, que conduzem a uma idéia só, a da democracia perfeita de mão única: a democracia do partido único, do livro único, da idéia única. A idéia única, a idéia mórbida não pode ter lugar nesta Casa, que não pertence a ninguém, senão a todos. A democracia é um processo imperfeito em constante evolução, politicamente considerada por CHURCHILL o pior dos regimes, apenas melhor do que os experimentados e em experiência, e filosoficamente vista por BOBBIO como o pior dos bons regimes e o melhor dos maus regimes. Exatamente essas as virtudes da democracia. 
A formação de um lider em uma sociedade democrática é um processo lento e penoso. $O$ líder não surge, o líder se forja e se aperfeiçoa na luta diária, indormida, em busca dos seus ideais democráticos, porque em estados totalitários de partido único não há lideres, há chefes.

0 que nós, professores concursados nesta Casa e dela orgulhosos, queremos, é a confraternização em um debate infindável, em um debate de gerações, em um debate criador. A idéia do Direito repousa sobre dois fatos entrelaçados e interdependentes: a constituição da sociedade política, que BOBBIO diz ser pela força, monopólio do poder político, $e$ o exercício do poder político. Apenas que, constituída, a sociedade política tem a obrigação de regular e de limitar o uso desse monopólio.

Por tudo isso, ou só por isso, para mim ou a Faculdade de Direito é o eterno embrião de uma Universidade, no sentido do universo que discute, ou não é nada. Estou disposto, iconoclasta que sempre fui, a buscar esse tipo de Faculdade de Direito. Nos defeitos com que nasci e aperfeiçoei - falta o da covardia, que conduz ao imobilismo.

Se eu não puder acertar sempre, tenham a certeza de que procurarei, ao menos, ser sempre justo. E se, ao término da minha administração, puder dizer que iniciei, com a indispensável ajuda dos corpos docente, discente e funcional, o encontro de uma tal Faculdade de Direito, sentir-me-ei recompensado. Se, além disso, tiver conseguido o respeito dos meus pares, dos alunos e dos funcionários desta Casa, sentir-me-ei mais: sentir-me-ei orgulhoso. Pois então terá valido todo o esforço e sacrifício.

Disse.

Curitiba, novembro de 1984. 